\title{
Sprawozdanie z ogólnopolskiej konferencji naukowej "Obszary poradnictwa i wsparcia społecznego. Tradycyjne i alternatywne strategie, formy, metody pomocy" (Poznań, 22 października 2014 r.)
}

22 października 2014 r. na Wydziale Studiów Edukacyjnych Uniwersytetu im. Adama Mickiewicza w Poznaniu pod patronatem dziekana - prof. zw. dr. hab. Zbyszka Melosika - odbyła się ogólnopolska konferencja naukowa „Obszary poradnictwa i wsparcia społecznego. Tradycyjne i alternatywne strategie, formy, metody pomocy", zainicjowana przez Zakład Poradnictwa Społecznego. W organizacji przedsięwzięcia uczestniczyli: prof. zw. dr hab. Magdalena Piorunek (przewodnicząca komitetu organizacyjnego), dr hab. Marek Budajczak, dr Grażyna Teusz, dr Joanna Kozielska, mgr Agnieszka Skowrońska-Pućka (sekretarz konferencji) oraz mgr Aneta Baranowska, a także członkowie Studenckiego Koła Naukowego Poradnictwa Społecznego "poMOC".

Konferencja ta była trzecim wydarzeniem tego typu w cyklu organizowanym przez Zakład Poradnictwa Społecznego Wydziału Studiów Edukacyjnych UAM. Wcześniej - 16 kwietnia 2010 r. - odbyła się konferencja, podczas której rozważania prelegentów oscylowały wokół problematyki związanej z "poradnictwem i wsparciem społecznym w biegu życia człowieka". Podjęte zagadnienia, wzbogacone refleksją na podstawie własnych doświadczeń, stały się hasłami przewodnimi dwóch zbiorowych publikacji pod redakcją prof. zw. dr hab. Magdaleny Piorunek: Pomoc - wsparcie spoteczne - poradnictwo. Od teorii do praktyki (2010) oraz Poradnictwo. Kolejne przybliżenia (2011). 
„Dziecko - młodzież - rodzina jako adresaci pomocy psychopedagogicznej i socjalnej" to tytuł drugiej konferencji zorganizowanej w ramach wspomnianego cyklu (w 2012 r.). Wzięli w niej udział reprezentanci ponad 30 krajowych ośrodków akademickich i instytucji pomocowych, których artykuły ukazały się w monografii naukowej Rodzina. Młodzież. Dziecko. Szkice $z$ teorii i praktyki pomocy psychopedagogicznej i socjalnej pod redakcją M. Piorunek, J. Kozielskiej oraz A. Skowrońskiej-Pućki.

Tegoroczna konferencja stanowiła odpowiedź środowiska pedagogów i przedstawicieli nauk społecznych na dynamicznie dokonujące się "przemiany kulturowo-gospodarcze na poziomie makrospołecznym, prowadzące do zmiany stylu życia ludzi, przyczyniające się do powstawania szeregu problemów, trudności, kryzysów biograficznych"1, a tym samym - na wzrastające zapotrzebowanie na szeroko rozumiane poradnictwo oraz wsparcie społeczne. Jak podkreśliła w mowie wstępnej prof. zw. dr hab. Magdalena Piorunek, "sytuacje nowe, do tej pory niespotykane, nieprzewidywalne w życiu jednostek, grup i społeczności, generują potrzeby, których zaspakajanie wymaga różnych form zewnętrznego wspomagania. Zmienia się jednak nie tylko natura i charakter tych potrzeb, ale i strategie, metody, formy i środki jej świadczenia i organizowania. [...] pomoc przybiera coraz subtelniej zróżnicowane formy, które współwystępują w społecznej rzeczywistości i konweniują lub wręcz zachodzą znaczeniowo na siebie w nomenklaturze naukowej. Wszak w obrębie działań pomocowych możemy mówić o profilaktyce pierwotnej [...], o terapiach psychopedagogicznych [...]. Możemy także wskazać na szereg form aktywności, których celem jest optymalizowanie funkcjonowania jednostek i grup społecznych, bazujące na wykorzystaniu ich wewnętrznych i zewnętrznych zasobów oraz posiadanego potencjału rozwojowego - będą wśród nich różne odmiany coachingu, tutoringu, mentoringu. Te zróżnicowane formy działań pomocowych bazują często na odmiennych założeniach teoretycznych, adresowane są do odmiennych kategorii osób, posługują się zróżnicowanym arsenałem strategii, metod i środków działania, zarówno tradycyjnych, klasycznych, niejako przypisanych interakcji wspierający - wspierany, jak i alternatywnych, nowych, do tej pory niewykorzystywanych $\mathrm{w}$ tego typu przedsięwzięciach" ${ }^{2}$.

${ }^{1}$ M. Piorunek, maszynopis tekstu otwierającego ogólnopolską konferencję naukową „Obszary poradnictwa i wsparcia społecznego. Tradycyjne i alternatywne strategie, formy, metody pomocy", Poznań 2014.

2 Ibidem. 
Podstawowym założeniem organizatorów było stworzenie płaszczyzny umożliwiającej wymianę doświadczeń przedstawicieli teorii oraz praktyki zaangażowanych $\mathrm{w}$ tworzenie warunków i świadczenie usług poradniczych, we wsparcie, $\mathrm{w}$ pomoc. Istota podjętej problematyki miała przynajmniej trzy aspekty - była rozpatrywana:

- „z punktu widzenia społecznej praktyki ujawniającej stale ewoluujące, a także nowe potrzeby z zakresu pomocy i wsparcia społecznego oraz zapotrzebowania rynku pracy na specjalistów z zakresu pomagania

- w obrębie nauk humanistyczno-społecznych, w ramach których badania $\mathrm{z}$ zakresu poradoznawstwa realizowane są z uwzględnieniem różnych paradygmatów teoretycznych, w tym pozytywistycznego, interpretatywnego, emancypacyjno-krytycznego, postmodernistycznego

- w kształceniu na etapie edukacji wyższej na kierunkach pedagogicznych"3.

Konferencja została podzielona na dwie części. Pierwsza z nich, plenarna, miała na celu określenie problematyki obrad. Druga, panelowa, składała się z kilku sekcji tematycznych.

Jako pierwsza na sesji plenarnej wystąpiła przewodnicząca komitetu organizacyjnego i kierownik Zakładu Poradnictwa Społecznego prof. zw. dr hab. Magdalena Piorunek. Następnie głos zabrali kolejno: dziekan Wydziału Studiów Edukacyjnych prof. zw. dr hab. Zbyszko Melosik, który uroczyście otworzył konferencję, oraz prof. UAM dr hab. Kinga Kuszak prodziekan wydziału. Merytoryka trzech pierwszych wystąpień oscylowała wokół szeroko pojętego całożyciowego poradnictwa kariery. Prof. UKSW dr hab. Barbara Baraniak z Uniwersytetu Kardynała Stefana Wyszyńskiego w Warszawie w swoim wystąpieniu ukazała poradnictwo kariery postrzegane $\mathrm{z}$ perspektywy pedagogiki pracy. $\mathrm{Z}$ kolei prof. APS dr hab. Urszula Jeruszka z Akademii Pedagogiki Specjalnej w Warszawie wskazała na zagadnienia dotyczące poprawy zatrudnialności absolwentów szkół zawodowych, a także ich zapotrzebowania na różne formy wsparcia i poradnictwa. Reprezentująca Uniwersytet Wrocławski dr Violetta Drabik-Podgórna odwołała się do teorii biegu oraz przestrzeni życia D. Supera. Wskazała na istotę konstruowania życia jednostek. Prelegentka podkreśliła, że nie tylko projektowanie przestrzeni fizycznej, lecz także aranżowanie

3 Ibidem. 
przestrzeni życia wymaga specjalistów (architektów), których rolą jest aktywne doradzanie bądź wyłącznie towarzyszenie w procesie konstruowania życia człowieka. Następnie prof. UAP dr hab. Robert Bartel z Uniwersytetu Artystycznego w Poznaniu podjął refleksję nad zagadnieniami arteterapeutycznymi. Szczególny nacisk położył na terapeutyczne znaczenie portretu i autoportretu. W trzech kolejnych wystąpieniach przedstawiciele Wydziału Studiów Edukacyjnych Uniwersytetu im. Adama Mickiewicza w Poznaniu podejmowali problematykę wspierania dzieci i młodzieży w sytuacji wystąpienia zróżnicowanych problemów rozwojowych oraz edukacyjnych. Prof. UAM dr hab. Hanna Krauze-Sikorska zwróciła uwagę na trudności w uczeniu się w sytuacji tranzycji ze szkoły podstawowej do gimnazjum. Z kolei prof. UAM dr hab. Kinga Kuszak wygłosiła referat na temat poradnictwa i wsparcia rodziców dzieci z utrudnieniami w rozwoju mowy. Prof. UAM dr hab. Małgorzata Cywińska skoncentrowała swoje wystąpienie wokół profilaktyki i sposobów radzenia sobie z konfliktami interpersonalnymi wśród dzieci. Część plenarną obrad zamknęło wystąpienie dr Urszuli Tokarskiej, reprezentującej Uniwersytet Pedagogiczny w Krakowie. Prelegentka starała się podkreślić, iż w procesie wspomagania rozwoju człowieka ogromny potencjał ma możliwość kompilacji trzech nurtów psychologicznych: narracyjnego, egzystencjalnego i rozwoju człowieka w cyklu życia.

Z uwagi na niezwykłą różnorodność zgłoszonych referatów dalsze obrady odbyły się $\mathrm{w}$ czterech równoległych kilkugodzinnych sekcjach tematycznych, ukierunkowanych specjalistycznie. Każdą z nich podzielono na dwie części.

Moderatorami pierwszej sesji byli prof. UAM dr hab. Marek Budajczak oraz dr Katarzyna Waszyńska z Wydziału Studiów Edukacyjnych UAM. Motywem przewodnim podjętych rozważań stały się nowe, alternatywne metody pomocy psychopedagogicznej. Jako pierwszy wystąpił dr Marek Podgórny, reprezentujący Uniwersytet Wrocławski. Prelegent zogniskował swój referat wokół zagadnień związanych z coachingiem w kontekście wsparcia procesu zarządzania wiedzą osobistą. Problematykę tę $\mathrm{w}$ pewnym stopniu kontynuowali: mgr Laura Ćwikła, która omówiła kwestie związane z efektywnością procesu coachingowego, oraz dr Adam Zemełka (WSNHiD Poznań) - zaprezentował on zagadnienie wspierania rozwoju przez zastosowanie coachingu w aspekcie jego niedyrektywności. Mgr Eunika Jedynak z Uniwersytetu Mikołaja Kopernika w Toruniu ukazała coaching jako alternatywną formę wspierania rozwoju w pomocy socjalnej. 
Z kolei dr Katarzyna Waszyńska (WSE UAM) przedstawiła problematykę poradnictwa psychologicznego w cyberprzestrzeni. Reprezentująca Wydział Studiów Edukacyjnych UAM mgr Aneta Baranowska zwróciła uwagę na wykorzystanie tutoringu jako formy indywidualnego wsparcia uczniów ze specjalnymi potrzebami edukacyjnymi. Pierwszą część sesji zakończyło wystąpienie mgr Katarzyny Banaszak na temat mentoringu oraz jego egzemplifikacji w postaci Studenckiej Akademii Mentoringu.

Tematyka obrad z drugiej części pierwszej sesji (sekcja piąta popołudniowa) odnosiła się do zapotrzebowania na pomoc i wsparcie w systemie edukacyjnym. Sekcję tę moderowali: dr Iwona Werner (WSNHiD Poznań) oraz dr Kinga Lendzion (UKSW Warszawa). Referat otwierający wygłosiła dr Kinga Lendzion. Dotyczył on barier socjokulturowych w dostępie do edukacji dzieci w Afryce Subsaharyjskiej. Następnie głos zabrały prof. zw. dr hab. Magdalena Piorunek oraz dr Iwona Werner, które omówiły zagadnienia dotyczące szeroko rozumianych relacji uczeń - wychowawca oraz postrzegania nauczycieli jako osób będących źródłem wsparcia i pomocy, jakiej potrzebują gimnazjaliści. Z kolei dr Paulina Ratajczak (WSE UAM) oraz dr Maria Porzucek-Miśkiewicz (WSE UAM) zaprezentowały temat psychodydaktycznych aspektów funkcjonowania ucznia zdolnego w roli kozła ofiarnego. Kolejna prelegentka, dr Sonia Wawrzyniak (WSE UAM), poruszyła zagadnienia dotyczące współpracy nauczyciela z rodziną dziecka doświadczającego niepowodzeń szkolnych. Dr Maja Piotrowska z Uniwersytetu Wrocławskiego uwypukliła problem rozwodu w rodzinie - przedstawiła go jako wyzwanie dla współczesnego poradnictwa rodzinnego. Tematem wystąpienia kolejnej prelegentki, reprezentującej Wydział Studiów Edukacyjnych mgr Justyny Cieślińskiej, było zagadnienie diagnostyki specyficznych trudności $\mathrm{w}$ uczeniu się $\mathrm{z}$ perspektywy środowiska rodzinnego, szkolnego i poradni psychologiczno-pedagogicznej. Z kolei mgr Dominika Przybyszewska (WSE UAM) przedstawiła zagadnienia dotyczące roli partnerstwa edukacyjnego w świadczeniu pomocy uczniom o specjalnych potrzebach edukacyjnych w szkołach podstawowych. Jako ostatnia $\mathrm{w}$ tej części obrad wystąpiła mgr Sylwia Polcyn-Matuszewska (WSE UAM). Podjęła ona próbę analizy form pomocy i wsparcia uczniów z fobią szkolną w cyberprzestrzeni.

Pierwszą część drugiego panelu tematycznego, moderowaną przez dr Joannę Kozielską (WSE UAM) i dr Beatę Jakimiuk (KUL), poświęcono poradnictwu kariery. Jako pierwsza głos zabrała dr Beata Jakimiuk, która przedstawiła problemy dotyczące współczesnych karier oraz wynikających 
z nich implikacji dla systemu poradnictwa. Następnie dr Daniel Kulka z Akademii im. Jana Długosza w Częstochowie podjął rozważania na temat roli poradnictwa zawodowego jako elementu kształtowania przyszłości edukacyjno-zawodowej młodzieży. Obszar problemowy dotyczący doradztwa zawodowego przedstawiła również dr Joanna Nawój-Połoczańska, reprezentująca Uniwersytet Szczeciński. Przedstawiła ona omawiane zagadnienie z perspektywy potencjalnego narzędzia inkluzji obywatelskiej. W dalszej kolejności dr Anna Potasińska (UKSW Warszawa) wskazywała na skuteczność walki ze zjawiskiem bezrobocia poprzez zastosowanie odpowiedniej polityki rynku pracy. Dr Anna Kławsiuc-Zdunczyk (UMK Toruń) osadziła swoje rozważania w kontekście aktywizacji zawodowej osób z niskimi kwalifikacjami zawodowymi. Z kolei dr Robert Parol, reprezentujący Akademię Pomorską w Słupsku, omówił zagadnienie wsparcia aktywności edukacyjnej osób powyżej 50. roku życia. W dalszej kolejności wystąpiła dr Justyna Bluszcz (Akademia Pedagogiki Specjalnej im. Marii Grzegorzewskiej w Warszawie), która zaprezentowała rolę instytucji pomocy społecznej $\mathrm{w}$ procesie aktywizacji zawodowej podopiecznych. Dr Marian Piekarski, przedstawiciel Politechniki Krakowskiej, ukazał rolę badań przydatności zawodowej, a także jej użyteczności w poradnictwie zawodowym. Pierwszą część drugiej sesji tematycznej zakończyło wystąpienie dr Doroty Nawrat, którego motywem przewodnim była rola postrzeganego jako zadanie dla poradnictwa zawodowego zwiększania świadomości własnego zdrowia.

Drugą część sekcji moderowały dr Joanna Kozielska oraz mgr Aneta Baranowska. Pierwszy referat wygłosiła dr Izabella Kust (Wyższa Szkoła Menedżerska $\mathrm{w}$ Warszawie). Prelegentka przedstawiła rolę i znaczenie systemowych rozwiązań promocji zatrudnienia oraz rynku pracy. Następnie mgr Jacek Brzeziński (UKSW Warszawa) ukazał potrzeby doradców zawodowych w kształtowaniu świadomości ekologicznej społeczeństwa. Dr Aleksandra Kulpa-Puczyńska (UKSW Warszawa) zwróciła uwagę na telecentra $\mathrm{w}$ kontekście nowej przestrzeni dla rozwoju poradnictwa i wsparcia społecznego. Z kolei dr Joanna Kozielska z Wydziału Studiów Edukacyjnych UAM w Poznaniu swoje wystąpienie poświęciła problemowi wsparcia emigrantów na rynku pracy. Wsparcie $w$ aspekcie adaptacji kulturowo-społecznej polskich emigrantów w Niemczech stało się tematem wystąpienia kolejnej prelegentki, dr Magdy Kalkowskiej, reprezentującej Akademię Wychowania Fizycznego i Sportu w Gdańsku. Dr Joanna Michalak-Dawidziuk (Wyższa Szkoła Menedżerska w Warszawie) dokonała 
oceny jakości poradnictwa edukacyjno-zawodowego z perspektywy studentów pierwszego roku. Następnie mgr Magdalena Brzozowska z Uniwersytetu Zielonogórskiego przedstawiła uczniowskie firmy jako nową propozycję rozwiązań w zakresie umacniania związków szkoły i rynku pracy w Niemczech. W dalszej kolejności mgr Wioletta Duda, reprezentująca Akademię im. Jana Długosza w Częstochowie, ukazała szanse oraz zagrożenia wynikające z doradztwa zawodowego „na odległość”. Reprezentująca Wydział Studiów Edukacyjnych UAM mgr Lucyna Myszka podjęła temat dylematów związanych z rozmową doradczą we współczesnej rzeczywistości społecznej. Tę część obrad zakończył lic. Tomasz Kasprzak (WSE UAM), który omówił zagadnienia związane z poradnictwem zawodowym adresowanym do osób z niepełnosprawnością.

Obradom trzeciej sekcji tematycznej, osadzonej w problematyce wsparcia i pomocy w sytuacji choroby oraz konieczności profilaktyki zdrowotnej, przewodniczyły dr Ewa Kaperek-Golimowska oraz dr Astrid Tokaj. Tę część otworzyło wystąpienie dr Marii Brodzikowskiej (Uniwersytet Jagielloński w Krakowie), poświęcone problematyce wsparcia rodziny $\mathrm{z}$ osobą seropozytywną. Następnie głos zabrała dr Aneta Jarzębińska z Uniwersytetu Szczecińskiego, która przedstawiła alternatywne źródła wsparcia, takie jak forum dyskusyjne. Z kolei dr Justyna Deręgowska (WSNHiD Poznań) odniosła się do problemów związanych z profesjonalną komunikacją w opiece zdrowotnej, ze szczególnym uwzględnieniem aspektu wsparcia pracowników medycznych i pacjentów. Reprezentująca Uniwersytet Wrocławski mgr Kaja Koronkiewicz dokonała charakterystyki internetowego wsparcia społecznego osób chorych na raka piersi. Dr Astrid Tokaj (WSE UAM) podjęła próbę zaprezentowania roli wspomnień we wsparciu seniora. Problematykę tę kontynuowała dr Danuta Krzysztofiak z Wielkopolskiej Wyższej Szkoły Społeczno-Ekonomicznej w Środzie Wielkopolskiej. Prelegentka wskazała miejsce osoby starszej w kontekście działań pomocowych. Dr Ewa Wyrwich-Hejduk, reprezentująca Akademię Pedagogiki Specjalnej im. Marii Grzegorzewskiej w Warszawie, przedstawiła wyniki autorskich badań mówiące o tym, iż dziadek może stanowić „instytucję" wspierającą we współczesnej rodzinie, ciągle jeszcze niedocenianą lub wręcz pomijaną $\mathrm{w}$ dyskursie naukowym. Reprezentująca Wydział Studiów Edukacyjnych UAM dr Ewa Kasperek-Golimowska skoncentrowała swoje rozważania wokół osobistej odpowiedzialności za własne zdrowie. Ostatni referat w tej części obrad wygłosiła dr Małgorzata Grzywacz (UAM Poznań). Przedstawiła ona aspekty etyki ewangelickiej oraz 
rytuały wsparcia przez wybrane Kościoły protestanckie w Republice Federalnej Niemiec w sytuacji poronienia.

Tematem wiodącym drugiej części obrad tej sekcji były różnorodne strategie, formy i metody wspierania dzieci $w$ trudnych sytuacjach. Sesję tę moderowały dr Aneta Mac (WSE UAM) oraz dr Agata Matysiak-Błaszczyk (WSE UAM). Rozważania merytoryczne rozpoczęły dr Renata Śleboda oraz dr Patrycja Rąglewska z Akademii Wychowania Fizycznego w Poznaniu wystąpieniem na temat wsparcia rozwoju psychomotorycznego dziecka poprzez zajęcia ruchowe z elementami jogi oraz kinezjologii. Z kolei dr Monika Nawrot-Borowska, reprezentująca Uniwersytet Kazimierza Wielkiego w Bydgoszczy, oraz mgr Agnieszka Małek z Akademii Wychowania Fizycznego i Sportu w Gdańsku przedstawiły charakterystykę wychowania zdrowotnego oraz higieny dzieci i młodzieży w perspektywie historycznej. Następnie głos zabrała dr Eliza Czerka-Fortuna (Uniwersytet Gdański), która w swoim referacie pokazała metody i techniki pracy doradczej oraz terapeutycznej z dziećmi $\mathrm{w}$ wieku szkolnym na podstawie studiów konkretnych przypadków, a jednocześnie zwróciła uwagę na zasoby i trudności pojawiające się w kontakcie z dzieckiem oraz jego rodziną. Dr Anna Gulczyńska (WSE UAM) oraz dr Barbara Jankowiak (WSE UAM) dokonały charakterystyki "Game-Based Therapy” jako metody pomocy i wsparcia dzieci - ofiar przemocy seksualnej. Z kolei dr Agata Woźniak (GSW Milenium) omówiła "Podejście skoncentrowane na rozwiązaniach" w poradniach i konsultacjach dla rodziców dzieci w wieku przedszkolnym. Mgr Lidia Szmania (WSE UAM) wygłosiła referat z pogranicza teorii i praktyki, w którym odniosła się do wsparcia rodziców dzieci ze spektrum autyzmu. Dr Agata Matysiak-Błaszczyk (WSE UAM) swoje wystąpienie poświęciła problemowi (na podstawie badań własnych) innowacyjnych programów wychowawczych realizowanych w Domu Matki i Dziecka w Krzywańcu. W dalszej kolejności głos zabrała mgr Agnieszka Król z Uniwersytetu Jana Kochanowskiego w Kielcach. Jej referat poruszał temat pomocy społecznej w kontekście funkcjonowania dzieci z obszarów wiejskich. Następnie mgr Justyna Kuświk, reprezentująca Uniwersytet Szczeciński, poruszyła zagadnienia organizacji wsparcia terapeutycznego oraz zajęć psychoedukacyjnych dla dzieci i młodzieży z zagrożeniem niedostosowania społecznego. Jako ostatnia w tej części tematycznej głos zabrała mgr Anna Parysek (WSE UAM), która przedstawiła coaching rodzicielski.

Zespołowi czwartemu przewodniczyły dr Grażyna Teusz oraz dr Barbara Jankowiak, reprezentujące Wydział Studiów Edukacyjnych UAM. 
Pierwszą część obrad na temat pracy socjalnej, pomocy rodzinie i osobom niedostosowanym społecznie rozpoczęło wystąpienie dr Katarzyny Kuziak z Uniwersytetu Mikołaja Kopernika w Toruniu. Prelegentka poruszyła temat alternatywnych rozwiązań $\mathrm{w}$ obszarze wsparcia społecznego młodzieży zagrożonej wykluczeniem społecznym. Szczególną uwagę zwróciła na usamodzielniającą się młodzież. Temat ten kontynuowała dr Anna Dąbrowska (Wyższa Szkoła Biznesu i Przedsiębiorczości w Ostrowcu). Zaakcentowała ona rolę indywidualnych oddziaływań resocjalizacyjnych w przypadku młodzieży nieprzystosowanej społecznie. Dr Barbara Jankowiak oraz dr Emilia Soroko, reprezentujące Wydział Studiów Edukacyjnych UAM, skoncentrowały się na wsparciu w socjoterapii. Następnie dr Ewa Bilska z Akademii Pedagogiki Specjalnej im. Marii Grzegorzewskiej w Warszawie scharakteryzowała placówki pomagające ofiarom przemocy $\mathrm{w}$ rodzinie $\mathrm{z}$ punktu widzenia ich klientów. Temat ten podjęła także mgr Joanna Jezierska z Uniwersytetu Gdańskiego, która ukazała kryzys jako szansę oraz zagrożenie (na podstawie pracy z klientami Centrum Interwencji Kryzysowej PCK w Gdańsku). Z kolei mgr Agnieszka Skowrońska-Pućka (WSE UAM) odniosła się do osobistych doświadczeń zawodowych - wskazała i scharakteryzowała (nie)tradycyjną strategię wdrażania do odpowiedzialnego rodzicielstwa wychowanków placówek opiekuńczo-wychowawczych. Mgr Bożena Kanclerz (WSE UAM) przedstawiła formy pomocy oraz wsparcia dla młodzieży niedostosowanej społecznie z perspektywy kuratorów sprawujących nadzór nad nieletnimi. W tej części obrad jako ostatni wystąpił mgr Mariusz Żyta (UKSW Warszawa), który tematem swojego referatu uczynił pomoc psychologiczno-pedagogiczną adresowaną do osób uczących się w szkołach dla dorosłych.

Druga część czwartej sekcji była moderowana przez dr Ewę Włodarczyk (WSE UAM) oraz mgr Agnieszkę Skowrońską-Pućkę (WSE UAM). Obrady rozpoczęło wystąpienie dr Anny Gutowskiej, reprezentującej Uniwersytet Łódzki, która przedstawiła teoretyczne koncepcje wsparcia społecznego. Następnie dr Kamila Słupska (WSE UAM) dokonała charakterystyki organizacji pozarządowych i ich działań na rzecz młodzieży. Mgr Robert Kostański z Miejskiego Ośrodka Pomocy Rodzinie w Poznaniu zaprezentował standaryzację metodyki pracy socjalnej jako innowacyjnej formy pracy realizowanej w Miejskim Ośrodku Pomocy Rodzinie w Poznaniu. Mgr Sylwia Łysakowska (Pedagogium WSNS Warszawa) tematem swojego wystąpienia uczyniła rodzinę zastępczą jako formę wsparcia społecznego dla rodzin dysfunkcyjnych. Wystąpienie mgr Anny Michniuk 
(WSE UAM) oscylowało wokół problematyki wsparcia społecznego adolescentów w rodzinie pełnej i niepełnej. Następnie dr Ewa Włodarczyk (WSE UAM) scharakteryzowała sytuację kobiet uzależnionych od alkoholu z perspektywy pracowników socjalnych. Lic. Dorota Dolata (WSE UAM) zaprezentowała efektywność pomocy świadczonej przez grupy samopomocowe DDA oraz grupy terapeutyczne DDA z punktu widzenia ich uczestników. W dalszej kolejności mgr Aneta Judzińska (WSE UAM) oraz lic. Kinga Englot (WSE UAM) ukazały specyfikę pracy asystenta rodzinnego w aspekcie społeczno-kulturowym. Podsumowanie tej części rozważań stanowiło wystąpienie dr Mikołaja Bręka (WSE UAM), który omówił relacje pomiędzy służbami społecznymi a żebrakami w perspektywie historycznej.

Należy zauważyć, że w wystąpieniach konferencyjnych zaprezentowano liczne ważne zagadnienia o charakterze teoretyczno-empirycznym oraz przedstawiono alternatywne metody wsparcia i pomocy odpowiadające potrzebom współczesnego człowieka. Duże zainteresowanie prelegentów oraz frekwencja słuchaczy zarówno podczas głównej sesji plenarnej, jak i sesji tematycznych stanową dla organizatorów Zakładu Poradnictwa Społecznego czynniki motywujące do kontynuowania konferencyjnych spotkań osadzonych w podjętej tematyce. 